\title{
FLT3 Inhibitor FF-10101 Succinate
}

National Cancer Institute

\section{Source}

National Cancer Institute. FLT3 Inhibitor FF-10101 Succinate. NCI Thesaurus. Code C137988.

The succinate salt form of FF-10101, a FMS-like tyrosine kinase 3 (FLT3; CD135; ST K1;

FLK2) inhibitor, with potential antineoplastic activity. Upon administration of FLT3 inhibitor FF-10101 succinate (FF-10101-01), FF-10101 irreversibly binds to and inhibits the activity of FLT3. This inhibits the proliferation of FLT3-expressing cancer cells. FLT3, a class III receptor tyrosine kinase (RTK), is overexpressed or mutated in most $B$ lineage neoplasms and in acute myeloid leukemias. 